
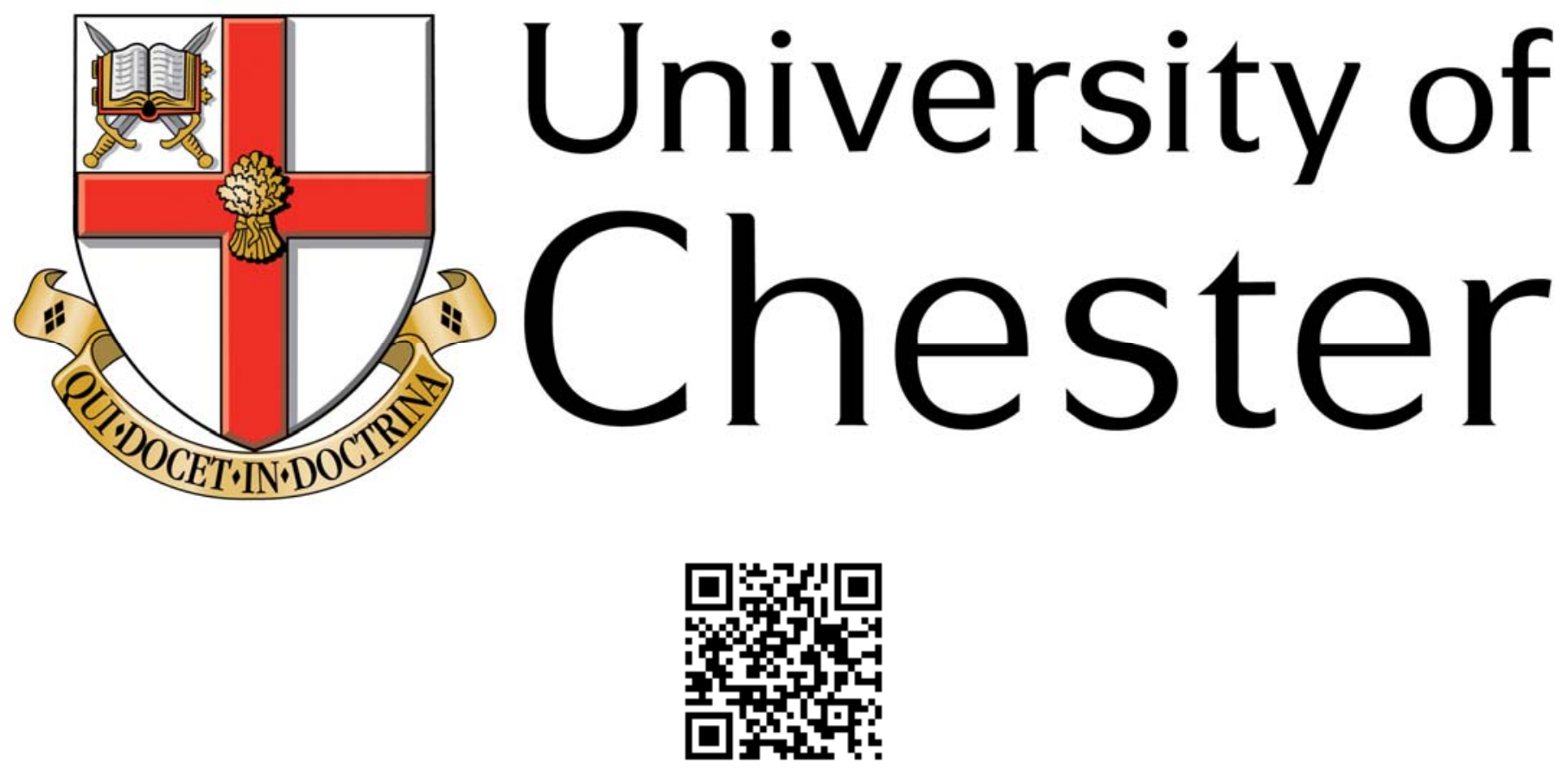

This work has been submitted to ChesterRep - the University of Chester's online research repository

\title{
http://chesterrep.openrepository.com
}

Author(s): Celia Deane-Drummond

Title: Development and environment: In dialogue with liberation theology

Date: 1997

Originally published in: New Blackfriars

Example citation: Deane-Drummond, C. (1997). Development and environment: In dialogue with liberation theology. New Blackfriars, 78(916), 279-289.

Version of item: Author's post-print

Available at: http://hdl.handle.net/10034/14633 


\section{Development and Environment: in Dialogue with Liberation Theology}

\section{Celia Deane-Drummond}

There was indeed a time when Environment and Development were not on speaking terms...Those who loved the environment regarded those who championed progress and 'development' as the enemy, and those who wanted to develop the poorest peoples and nations felt that much of the 'environment' would have to be sacrificed in this worthwhile endeavour.(1)

It is only comparatively recently that there has been an attempt to examine issues in environment and development together, rather than separately. The shift in attitude by the greens came as a result of the realisation that poor nations are forced to destroy their environment in order to survive and by the developers as a result of a new awareness that policies which destroy the very basis for change are invalid. The broad agreement in the notion that both environment and development are interconnected applies regardless of the particular models of development or environment.(2)

Liberation theology identifies with a particular model of development which arose at a time when the global and political implications of environmental issues were largely ignored. It is, therefore, hardly surprising that environmental concerns are rarely, if ever, mentioned in the classical texts. The purpose of this paper is to explore both the challenge of the environment to liberation theology and its possible contribution to an inclusive environmental theology. Some models of development are more likely to be compatible with particular environmental philosophies.(3) What contribution, if any, can liberation theology make to the current debate? 
In the post-war era the conventional wisdom of the so-called 'modernisation' theory held that in order to achieve development so called 'underdeveloped' nations must adopt a profit incentive and find ways and means for economic productivity.(4) More 'advanced' countries provided the missing components in order to 'boost' the fledgling economy. The implication is that economic growth creates conditions for democracy, so that economic and democratic stability are part of the same package.

The alternative view, known as 'dependency' theory, gradually emerged and set out to challenge the modernisation thesis.(5) Dependency theory drew on some Marxist principles in that it attacked the capitalist system. Nonetheless, it was a modified version of Marxism since Marx believed that the economic and technical components were necessarily provided by the 'advanced' countries.(6) In Marxist philosophy socialism could only be successful after capitalist modes of production had produced the requisite wealth.

Andre Gunter Frank, writing in the late 1960s, was one of the pioneers of dependency theory.(7) He believed that underdeveloped nations stayed that way in order to support further growth of advanced capitalist countries. Frank called for a revolutionary break from capitalism. Latin America would remain 'stagnant' because any accumulated capital was appropriated by foreign monopolies or domestic elites. The 'development of underdevelopment' were two sides of one coin. Fernando Henrique Cardoso's version of dependency theory was more modest.(8) While he agreed that Latin America could only be understood by reference to its dependency on advanced capitalist nations, he focused primarily on internal social factors as opposed to external agents. His ideas about dependency which challenged the concentration of power in an elite minority groups raised political questions. Both Frank and Cardoso have been criticised for oversimplification, 
though Cardoso at least attempts to avoid general theorisation and concentrates on specific situations of dependency.

Many Latin American liberation theologians have drawn on dependency theory in an explicit way as a basis for their theological reflection. Gustavo Gutierrez prefers the term 'liberation', rather than 'development', arguing that both processes are correlated:

The term liberation avoids the pejorative connotations which burden the term development. At the same time, it is the logical expression of the most profound possibilities contained in the process known as development. In addition, the term development somewhat obscures the theological problems raised by this process. By contrast, the expression liberation leads us easily to the biblical sources which inspire the presence and action of man in history.(9)

Gutierrez draws most heavily on Cardoso for his analysis of dependency theory. In his more recent work The Power of the Poor its History he states that 'external dependency and internal domination are marks of the social structures of Latin America'.(10) The political issues raised by internal domination by elite groups are a main focus for his theological reflection. It is easy to see how, given this attention to internal political questions, environmental issues do not appear on the agenda. He believes that in spite of its shortcomings dependency theory 'has by and large been a boon', since in the 1960s it 'helped the popular class to reject the politics of compromise and conformism during that decade'.(11) Furthermore, he agrees that the fundamental problem is not so much conflict between the rich centre nations and the poor periphery, but between social classes.(12)

Leonardo Boff also portrays Latin America as dependent. Although he uses Frank's analysis he cautions against giving dependency theory any status higher than part of an ongoing investigation. A constant theme is that both Marxist analysis and social theory are 
useful instruments, rather than the final word. For 'The oppressed are more than what the social analysts- economists, sociologists, anthropologists - can tell us about them. We need to listen to the oppressed themselves'(13) Some of Boff's remarks are related to the fact that liberation theology has been severely attacked for its Marxist leanings by church authorities.(14) Furthermore, the economist Peter Moll argues that liberation theologians still take dependency theory for granted in ignorance of the economic data.(15) He is somewhat scathing in his remark that 'they were intellectually ill-prepared to assess the merit of competing economic theories of development'.(16) He also criticises their reliance on a form of dependency theory which, according to him, 'not only obscured their understanding of economic justice, but also diverted attention away from one of the most important sources of economic weal or woe, namely national policy'.(17) Moll, in his turn has been criticised for failing to appreciate the contribution of liberation theologians to the dependency debate. More important, perhaps, Moll seems to screen out other voices by his insistence that all need to become experts in economics.(18) Perhaps it is fair to say that while dependency theory raises a number of broad questions about social, political and economic structures, it fails to point to concrete solutions. Liberation theologians have used dependency theories as a starting point for their theological questions and subsequent resolution. However, the underlying social and political questions remain unresolved.

While the details of dependency theory have come under fire, the search for alternative models of development has led to a much greater recognition of the importance of locating development in the heart of the local community.(19) Emerging theories of development have to take into account the growing recognition of the political and global importance of environmental issues. Hence, a radically different form of development would not only be 
endogenous, but also ecologically sound, that is 'utilising rationally the resources of the biosphere in full awareness of the potential of local eco-systems as well as the global and local limits imposed on the present and future generations'.(20)

From this beginning, the idea of 'sustainable development' has become an overarching concept which recognises the links between environment and development. Unfortunately the term 'sustainability' can be used in a number of different ways.(21) In a broad political context it is usually the sustainability of human society that is being referred to.

Sustainable use is part of the general concept and refers to the need to ensure the use of resources to allow the sustainability of human society. In a more specific sense sustainability 'refers to components contributing to the sustainability of society, that is: population, consumption, resource use and pollution.'(22) The complex nature of each of these components means that it is far from clear what constitutes sustainable policies. For example, resources are distinguished by their renewable and non-renewable nature, whether they are living or not and whether they are 'natural' or 'man-made'. Protagonists of sustainability can allow for the substitution of one resource for another, without taking into account the global environmental effects.(23) The main ethical thrust behind the idea of both sustainability and sustainable development seems to be the obligation to future generations, which is highly contentious.(24) However, if the notion of intragenerational justice is included then sustainability can be linked with present and future development.

Some environmental ethicists have rejected the idea of sustainable development altogether as 'irredeemably anthropocentric'.(25) It seems to me that this is only true if sustainability is used in a narrow sense to describe economic factors leading to reduced environmental risk. These risks have to be weighed up in order to maintain a privileged 
position in the market. In practice this means that restraint is based on the legality or otherwise of the action in a particular nation. The alternative, broader view of sustainability is one which is an ethical ideal of life on earth. This approach recognises that environmental value is much wider than measured by economic means. It includes a holistic approach to the natural world which stresses the inseparability of human beings and their environment.

In view of the ambiguity of both the terms sustainability and development I will be adopting the term 'holistic development' to imply a model of development which is organic, rather than mechanistic. However, I do not intend to imply that I am endorsing the 'deep green' philosophy of Naess and others.(26) In speaking of the ethics of environment and development there is a tendency to set up radical alternatives of either a mechanistic/Cartesian world view or an ecological/holistic world view.(27) The former is characterised by splits between fact and value, ethics and life, subject and object. 'Nature' is seen as discrete, material resources with instrumental value. This view seemingly leads to a centralisation of power, competitive attitudes and undifferentiated economic growth. The latter is characterised by a close relationship between fact and value, ethics and life, subject and object. 'Nature' is made up of interrelated wholes which are given intrinsic as well as systemic value.(28) It leads to decentralisation of power, a multidisciplinary approach, cooperative thinking and steady-state economy. When the alternatives are posited in this way it is hard to visualise any alternative other than radical replacement/revolution. The language of revolution identifies with the early writing of liberation theologians. How far has this language become modified in view of the practical realities of implementing change? It seems to me that liberation theology may have an important contribution to make in discerning practical ways forward for a more holistic 
development.

The focus on endogenous development at the heart of the local community coheres well with Christian base communities in Latin America fostered by the ideals of liberation theology.(29) Thierry Verhelst has argued that liberation theology has acted as a powerful impetus for resistance to cultural alienation.(30) Nonetheless, he cautions against a simple adoption of liberation theology by other cultures. He comments:

In the East the term liberation has different connotations than in Europe or Latin America. Asia is the cradle of all the major written religions. One would hardly expect its conception of liberation to be secular or basically socio-economic. For both Hinduism and Buddhism, liberation is achieved through a primarily spiritual, inner experience. The message of Eastern spirituality is the following: it is not only exploitation, domination and material poverty that ought to become objects of the struggle for liberation, there is another poverty, at least as serious: that is engendered by self-interest and egocentrism. In the East this poverty is called Maya, illusion, and becoming aware of it represents the starting point of its spiritual journey.(31)

To the Eastern mind the preconceptions of liberation theology are still Western, even though liberation theology seems more equipped to answer the needs of the Third World.(32) An Asian theology and spirituality of liberation 'finds its inspiration above all in the spiritual asceticism of the individual, for the oriental tradition of renunciation cannot be ignored'.(33) In Asia the totality of human experience: personal and communal, mystical and social replaces the social praxis of Latin American liberation theology. It seems to me that this emphasis on the totality of experience is more amenable to a theology for holistic development. Even though there is truth in the suggestion that theologies and spiritualities have to emerge from local culture, it is possible to learn from and be challenged by alternative perspectives. If total enculturation took place to the exclusion of external influences, I doubt whether there could be any sense of global community. In other words, 
the practical vision of what is possible at a local level can be modified by global considerations. The ecological crisis would seem to demand such global interests.

However, Verhelst's designation of East/West liberation theologies does not take into account the contribution of indigenous theologies, including native American theologies. In a recent book EcoTheology: Voices from South and North environmental questions are placed firmly in the context of human ecology and development.(34) The role of indigenous cultures is stressed, but there is a tendency for overgeneralisation, such as 'the underlying cause is essentially the replacement or domination of the "culture of life" of the indigenous, non-industrialised peoples by a "culture of death" characteristic of the rich and powerful in the industrialising and industrialised countries.'(35) The theologies from indigenous cultures, or Fourth World, wish to stress their distinctive contribution in terms of a revelation of God in place, taking their cues from Old Testament themes. They believe that the Third World Liberation theologians still take their cues from western culture. Liberation theology, by looking to models of liberation in Asia and the Fourth World can become more inclusive of environmental interests. Leonardo Boff seems to have taken this to heart in his suggestion that the planet becomes 'a great sacrament of God, the temple of the Spirit, the place of creative responsibility for human beings, a dwelling place for all beings created in love'.(36)

Another significant book in this context is a recent issue of Concilium, edited by Leonardo Boff and Virgil Elizondo entitled Ecology and Poverty.(37) The book knits together issues of poverty and ecology and stresses the sacred earth traditions in indigenous cultures. Boff's contribution is particularly relevant for the present discussion where he asks whether liberation theology and ecology are alternatives, confrontational or complementary.(38) He 
seems to be coming close to the deep green philosophy of Naess when he suggests that 'Liberation theology should adopt the new cosmology of ecological discourse, the vision that sees the earth as a living superorganism linked to the entire universe'.(39) While I identify with his suggestion that liberation theology and ecological discourse can mutually complement one another and act as a bridge between North and South, I am unsure of his seeming ready identification with radical elements of the ecological movement. It is, however, natural that he identifies with radical ecology as this offers the strongest challenge to the status quo and is more in tune with the revolutionary message of classical liberation theology. In practice, however, contemporary liberation theologies have had to argue for reform, rather than revolution. The Christian base communities have not always proved to be the centres for revolutionary change implied by some liberation theology. Hewitt argues that the primary benefit of base communities has been to endear a sense of citizenship.(40) There is also a corresponding shift in the writing of liberation theology from Marxist to democratic ideals, from conflict to negotiation, from class struggle to solidarity with the poor.(41) In pressing for change in environmental/developmental policies a more moderate view which argues for reform, rather than radical change seems to me to be the more realistic option.

The theme of liberation can also apply to the relationship between human beings and the natural environment. First, there is liberation from an attitude which views science as an instrument of power over 'nature'. As Kothari points out:

The presumption that the role of science and technology was to develop nature in the service of humankind has turned out to be an illusion. It was based on a view of science itself as an instrument of human power over nature, other men and women, other forms of life and all the qualities of being that constitute the cosmic order. This must give place to the original purpose of science, namely seeking to understand the mysteries of nature with a deep sense of mystery and wonder.(42) 
The difficulty now is what will this deep sense of wonder mean in practice? Jürgen Moltmann has also addressed this issue in his belief that modern industrialised nations have led to humanity becoming trapped in a web of their own making.(43) Liberation becomes an all embracing concept which includes economic justice in the face of human exploitation, human dignity in the face of political oppression, human solidarity in the face of alienation and division, peace with nature in the face of industrial destruction and hope in the face of apathy towards the whole.(44) Moltmann recognises interconnections between different forms of oppression and so, by implication, the need for cooperation between different forms of liberation. A similar point has been made recently by Boff and Elizondo in their identification of the 'Cry of the Earth' with the 'Cry of the Poor'.(45) Feminist theologians give priority to liberation of women from male domination as a prerequisite for right treatment of the environment.(46) The challenge remains: how are these theological ideals to be translated into practical policy?

The idea of liberation has been taken up by Gerald Kruijer, writing from a secular sociological perspective.(47) He believes that the social sciences have to liberate themselves from the need for abstract concepts and the quest for unbiased objectivity. A liberation science is science in the service of the liberation movement. He argues that data collected in the past have been biased against the poor. Moreover, everything that exists, 'including non-living matter' becomes part of the solidarity group.(48) The results of applied research done in this way have to be fed into policy formation. He argues that there is an intermediate stage between oppression and democratic socialism, namely undemocratic state socialism. He also offers some suggestions for socialist strategies and how to move from state socialism to democratic socialism. While many of Kruijer's ideas are controversial, he does at least offer come suggestions as to how to begin to implement 
realistic change. Taylor makes a similar point when he suggests that the real debate in development policy is not so much what is good, but what will work. An ethical critique can examine motives and consequences of policies, as well as offering some directives for future policy formation. In particular it will ask whose interests do decisions serve and what is the hidden agenda behind policy decisions.(49)

Sociological research has shown that in the developing world government conservation schemes tend to ignore the needs of the inhabitants and in some cases deprived them of their means of subsistence.(50) Non-governmental organisations fared slightly better, though very often they were 'deeply involved in conservation projects that were very similar to those of the government'.(51) If conservation is conducted in ignorance of the social consequences it is ultimately destructive as it works against the basic need for human justice. A related issue is that environmental protection against pollution is biased in favour of some communities over others. Minority communities are disproportionately subjected to a higher level of environmental risk.(52) Even the assurance of equal protection does not take into account the fact that disadvantaged communities are more vulnerable to pollution because of poor health.(53) The environmental justice movement presses for changes in environmental policy in order to take this into account. In the past concern with environmental issues has been thought of as a middle class luxury which pales into insignificance in the face of questions of survival amongst the world's poor. Yet it is clear that questions of survival and questions about the environment are intermeshed to the extent that the very survival of communities is dependent on taking into account environmental issues.

All these examples highlight the need to take into account both the social and 
environmental consequences of particular policies. While liberation theology originally conceived as social praxis does not take into account ecological issues, it is still relevant for discussions as it raises questions about human justice as part of a holistic approach to the environment. Furthermore, the idea of liberation can become enlarged to include the liberation of human beings from their desire for domination of the natural world. More extreme eco-philosophers can take heed of the adjustment of the revolutionary agenda of early liberation theology to a more modest goal of social reform. This social reform can include a reappraisal of the care for the natural environment so that development policy becomes holistic development, embedded in an ethic of environmental responsibility.

1 From foreword by Lloyd Timberlake in Dictionary of Environment and Development, A. Crump, ed., London, Earthscan Publications, 1991.

2 For scientific discussion see, for example, Environment, Population and Development, P. Sarre, ed., Milton Keynes, Open University, 1991.

3 See, D. Goulet, 'Development Ethics and Ecological Wisdom', in Ethics of Environment and Development: Global Challenges, International Response, J.R. Engel and J. G. Engel, eds., London, Belhaven Press, 1990, pp. 36-49.

4 For the steps needed for this economic growth see, W.W. Rostow, Stages of Economic Growth, Cambridge, Cambridge University Press, 1991.

5 Paul Prebisch, as director of the United Nations Commission on Latin America, laid the groundwork for the subsequent development of dependency theory by pointing out the negative trade effects of contact between 'underdeveloped' and 'advanced' countries. For a discussion see, A. F. McGovern, 'Latin America and Dependency Theory', This World, 14, 1986, pp. 104-123.

6 See, Preface to Capital, in Marx and Engels: Basic Writings on Politics and Philosophy, L. S. Feuer, ed., translated by S. Moore and E. Aveling, Glasgow, Collins/Fontana, 1969, pp. 174-187.

7 A.F. Frank, Capitalism and Underdevelopment in Latin America: Historical Studies of Chile and Brazil, New York, Monthly Review Press, 1969.

8 F.H. Cardoso, Dependency and Development in Latin America, Berkeley, University of California Press, 1979.

9 G. Gutierrez, 'The Meaning of development: Notes on a Theology of Liberation' in In Search of a Theology of Development, Sodepax Report, The Committee on Society, Development and Peace, Geneva, World Council of Churches, 1969, pp. 125-126. He makes a similar point in A Theology of Liberation revised edition. London, SCM Press, 1988, pp. 16-17.

10 G. Gutierrez, The Power of the Poor in History, London, SCM Press, 1983, p. 45. For a discussion of the relationship between liberation theology and dependency theory see W.R. Garrett, 'Liberation Theology and Dependency Theory', in The Politics of Latin American Liberation Theology: The Challenge In U.S. Public Policy, R.L. 
Rubenstein and J.K. Roth, eds., Washington, The Washington Institute Press, 1988, pp. 174-198.

11 G. Gutierrez, The Power of the Poor in History, London, SCM Press, 1983, p. 78.

12 Ibid., p. 192.

13 L. Boff and C. Boff, Introducing Liberation Theology, Tunbridge Wells, Burns and Dates, 1987, p. 30.

14 P.M. Heredia, 'Christianity and Liberation: A Cuban Study of Latin American Liberation Theology', Social Compass, 35 (213), 1988, pp. 309-342, see especially pp. 332-342.

15 P.O. Moll, 'Liberating Liberation Theology: Towards Independence From Dependency Theory', Journal of Theology for Southern Africa, 78, 1992, pp. 25-40.

16 Ibid., p. 36.

17 Ibid., pp. 38-39.

18 L. Cormill, 'Correspondence: Lee Cormill Responds to Peter Moll', Journal of Theology for Southern Africa, 82, 1993, pp. 88-94.

19 The idea of radical alternative development was pioneered by the Dag Hammarksjold Foundation in the late 1970s. See P. Ekins, A New World Order. Grassroots Movements for Global Change, London, Routledge, 1992, pp. 99-1 00.

20 Ibid., p. 100

21 R. Kothari, 'Environment, Technology and Ethics', in Ethics of Environment and Development: Global Challenges, International Response, J.R. Engel and J. G. Engel, eds., London, Belhaven Press, 1990, pp. 27-35.

22 C. Palmer, 'Some Problems with Sustainability', Studies in Christian Ethics, 7(1), 1994, pp. 52-62 (p. 53).

23 Ibid., pp. 54-55.

24 Ibid., p. 58.

25 H. Rolston 111, 'The Wilderness Idea Affirmed', The Environmental Professional, 13, 1991, pp. 370-377.

26 A. Naess, 'Sustainable Development and Deep Ecology', in Ethics of Environment and Development: Global Challenges, International Response, J.R. Engel and J. G. Engel, eds., London, Belhaven Press, 1990, pp. 87-96.

27 S.R. Sterling, 'Towards an Ecological World View', in Ethics of Environment and Development: Global Challenges, International Response, J.R. Engel and J. G. Engel, eds., London, Belhaven Press, 1990, pp. 77-86.

28 Ibid., p.82.

29 R. Robertson challenges the claim that Christian base communities are vehicles for liberation theology and suggests that in practice this purpose can be more ambiguous. R. Robertson, 'Liberation Theology, Latin America and Third World Underdevelopment', in The Politics of Latin American Liberation Theology: The Challenge to U.S. Public Policy, R.L. Rubenstein and J.K. Roth, eds., Washington, The Washington Institute Press, 1988, pp. 117-134.

30 T. Verhelst, No Life Without Roots: Culture and Development, translated by Bob Gumming, London, Zed Books, 1990, p. 158.

31 Ibid, p. 49. The theme of liberation is especially important in Latin American liberation theology, while that from an Asian/African origin tends to stress inculturation. The radical thrust of Latin American liberation theology has gradually moderated under the influence of the concept of enculturation. See R. Robertson, 'Liberation Theology, Latin America and Third World Underdevelopment' in The Politics of Latin American Liberation Theology: The Challenge to U.S. Public Policy, R.L. Rubenstein and J.K. Roth, eds., Washington, The Washington Institute Press, 1988, pp. 117-134. 
32 For a discussion of the integration of the cosmic and the metacosmic in an Asian theology of liberation and its rejection of the Western assumptions of Latin American liberation theology see, A. Pieris, An Asian Theology of Liberation, Edinburgh, $\mathrm{T}$ and T Clark, 1988. Also relevant is S. Ryan, 'The Search for an Asian Spirituality of Liberation' in Asian Christian Spirituality. Reclaiming Traditions, V. Fabella, P.K. Lee, D.Kwang-sun Suh, eds., Maryknoll, Orbis, 1992, pp. 11-30.

33 T. Verhelst, No Life Without Roots: Culture and Development, translated by Bob Gumming, London, Zed Books, 1990, p. 50. For additional comment on the relationship between the ethics of culture and ecology see, E. Dussel, Ethics and Community, Burns and Gates, 1988, pp. 194-204.

34 D. Hallman, ed., EcoTheology: Voices from South and North, Maryknoll, Orbis, 1994.

35 M. Sowunmi, 'Giver of Life- "Sustain Your Creation"' in EcoTheology: Voices from South and North, D. Hallman, ed., Maryknoll, Orbis, 1994, p 153. See also section called 'Insights from Indigenous Peoples', pp. 207-227, especially G. Tinker, 'The Full Circle of Liberation', pp. 218-224.

36 L. Boff, 'Social Ecology: Poverty and Misery', in ibid, p. 245.

37 L. Boff and V. Elizondo, eds., Ecology and Poverty, Concilium, 5/1995, London, SCM, 1995.

38 L. Boff, 'Liberation Theology and Ecology: Alternative, Confrontation or Complementary?' in ibid, pp. 67-77. In the same volume Rosino Gibellini makes the point that ecology as a theme in liberation theology has only emerged after the Rio de Janeiro conference in 1992, with the publication of the articles in a book edited by Boff entitled Ecology, World and Mysticism: The Emergence of a New Paradigm (Petropolis, 1993). R. Gibellini, 'The Theological Debate on Ecology', in L. Boff and V. Elizondo, eds., Ecology and poverty, Concilium, 5/1995, London, SCM, 1995, pp. 125-134.

39 L. Boff, 'Liberation Theology and Ecology: Alternative, Confrontation or Complementary?' in L. Boff and V. Elizondo, eds., Ecology and Poverty, Concilium, 5/1995, London, SCM, 1995, pp. 74-75.

40 W. E. Hewitt, 'Myths and Realities of Liberation Theology: The Case of Basic Christian Communities in Brazil', in The Politics of Latin American Liberation Theology: The Challenge to U.S. Public Policy, R.L. Rubenstein and J.K. Roth, eds., Washington, The Washington Institute Press, 1988, pp. 135-155.

41 See P.E. Sigmund, 'The Development of Liberation Theology: Continuity or Change?' in The Politics of Latin American Liberation Theology: The Challenge to U.S. Public Policy, R.L. Rubenstein and J.K. Roth, eds., Washington, The Washington Institute Press, 1988, pp. 21-47. Rubenstein argues that liberation theology leads to the adoption of middle class Western values. It seems to me that his suggestion that 'under the impact of liberation theology today's poor could become tomorrow's new secularised bourgeoisie' (p. 81) is exaggerated. See, R. Rubenstein 'Liberation Theology and the Crisis in Western Theology' in ibid, pp. 71-95.

42 R. Kothari, 'Environment, Technology and Ethics', in Ethics of Environment and Development: Global Challenges, International Response, J.R. Engel and J. C. Engel, eds., London, Belhaven Press, 1990, p. 34.

43 J. Moltmann, The Future of Creation, London, SCM, 1979, p.5.

44 Ibid., pp. 110-113.

45 L. Boff and V. Elizondo, 'Ecology and Poverty: Cry of the Earth, Cry of the Poor', in L. Boff and V. Elizondo, eds., Ecology and Poverty, Concilium, 5/1995, London, SCM, 1995, pp. ix-xii.

46 See, for example, A. Primavesi, From Apocalypse to Genesis. Ecology, Feminism 
and Christianity, Tunbridge Wells, Burns and Gates, 1991, R. Radford Ruether, Gaia and God: An Ecofeminist Theology of Earth Healing, London, SCM, 1992; S.

McFague, The Body of God: An Ecological Theology, London, SCM, 1993, E. Green and M. Grey, eds., Ecofeminism and Theology, Yearbook of the European Society of Women in Theological Research, Kampen, Kok Pharos, 1994.

47 G. Kruijer, Development Through Liberation. Third World Problems and Solutions, translated by A. Pomeraus, Basingstoke, Macmillan Education, 1987.

48 Ibid., pp. 32-33.

49 M. Taylor, Good for the Poor: Christian Ethics and World Development, London, Mowbray/Cassell, 1990, pp. 47ff

50 D. Ghai, ed., Development and Environment: Sustaining People and Nature, Institute of Social Studies, Oxford, Blackwell, 1994.

51 Ibid., p. 8.

52 T.W. Hartley, 'Environmental Justice: An Environmental Civil Rights Value Acceptable to all World Views', Environmental Ethics, 17, 1995, pp. 277-289.

53 For an analysis of how environmental justice affects environmental policy see V.Been, 'What's Fairness Got to Do with It? Environmental Justice and the Siting of Locally Undesirable Land Uses', Cornell Law Review, 78, 1993, pp. 1001-1085. 